\title{
Reviewing factors affecting the effectiveness of decentralised domestic wastewater treatment systems for phosphorus and pathogen removal
}

\author{
Joseph C. Akunna ${ }^{\mathrm{a}, *}$, Juliette M. O'Keeffe ${ }^{\mathrm{a}, *}$, Richard Allan ${ }^{\mathrm{b}}$ \\ 'Urban Water Technology Centre, School of Science, Engineering and Technology, Abertay University, Bell Street, \\ Dundee, DD1 1HG, UK, emails: j.o'keeffe@abertay.ac.uk (J.M. O'Keeffe) j.akunna@abertay.ac.uk (J.C. Akunna) \\ ${ }^{b}$ The James Hutton Institute, Invergowrie, Dundee, DD2 5DA, UK, email: Richard.Allan@hutton.ac.uk
}

Received 23 November 2016; Accepted 22 March 2017

\section{A B S T R A C T}

\begin{abstract}
Environmental pollution and risks to human health can result from diffuse sources of pollution originating from decentralised wastewater treatment systems (DWTS). In particular, phosphorus pollution can lead to eutrophication and the downgrading of the quality of water bodies, for example, under the Water Framework Directive in the EU, and pathogen pollution can result in increased risks of human exposure to pathogens and impacts on industries such as shellfish growing and tourism. The study reported in this paper reviews the effectiveness of various DWTS in removing phosphorus and pathogens from on-site systems. It was found that DWTS are typically not designed to specifically treat these pollutants, and the most common type of DWTS, septic tanks, provides only basic treatment. Additional treatment such as filtration-based or wetland systems must be used to achieve desired levels of treatments. The performance of these systems is affected by site-specific conditions, such as input load and sources, and climatic conditions, and as such operational characteristics and treatment measures must be designed to take account of these factors.
\end{abstract}

Keywords: Domestic wastewater; Pathogen removal; Phosphorus removal; Septic tanks; Wastewater treatment; Wetlands; Filtration-based treatment systems

\section{Introduction}

Domestic wastewater is a rich source of many potential environmental pollutants; however, phosphorus and pathogens have gained increasing attention in recent decades due to their potential impacts on human health, the environment and important sectors of the economy. High inputs of phosphorus to natural watercourses encourage algal growth that can degrade water quality. For example, the 2013 Water Framework Directive (WFD) classification identified $~ 9 \%$ of WFD baseline rivers and 21\% of WFD baseline lochs in Scotland as impacted by phosphorus in terms of their chemistry and ecology [1]. Both agricultural run-off and small point sources such as decentralised wastewater treatment systems (DWTS) contribute to inputs of phosphorus in surface waters

\footnotetext{
* Corresponding author.
}

in rural catchments but it has been reported that phosphorus discharges from DWTS, notably septic tanks (ST), may be more readily bioavailable for primary production in receiving waters than phosphorus in agricultural run-off, thereby giving them greater potential to degrade water quality [2]. Domestic wastewater is also a source of large numbers of faecal pathogens. Contamination of drinking water, shellfish, bathing waters and aquatic amenity sites by faecal pathogens from diffuse agricultural sources and human sources such as septic tank effluent (STE) increases the likelihood of waterborne illnesses being transmitted to human populations. DWTS discharges have been estimated to contribute $\sim 23.5 \%$ of the diffuse source Escherichia coli load (a common indicator for faecal pollution) or $7.6 \%$ of the total load (diffuse and point source) to Scottish groundwaters and surface waters [3].

Large numbers of households in rural areas in both developing and developed countries around the world are

Presented at the 13th IWA Specialized Conference on Small Water and Wastewater Systems \& 5th IWA Specialized Conference on Resources-Oriented Sanitation, 14-16 September, 2016, Athens, Greece.

1944-3994/1944-3986 @ 2017 Desalination Publications. All rights reserved. 
not connected to mains sewerage systems and therefore rely on the services of DWTS. For example, in rural Scotland $\sim 160,000$ properties are not connected to centralised sewerage systems and therefore rely on DWTS to treat their wastewater. These DWTS are mainly standalone STs or STs with post-treatment such as constructed wetlands or package systems. When used as standalone treatment units, STs have the highest potential for the discharge of phosphorus and faecal pathogens to the environment, aside from direct discharges. The reduction of phosphorus and pathogens by DWTS has typically been of secondary concern in system design, with optimisation of treatment tending usually to focus on removal of solids, organic pollutants and nitrogen.

The research reported in this paper aims to assess the performance of various DWTS in the removal of phosphorus and faecal pollutants from domestic wastewater. The review considers the impact of both traditional and new approaches to on-site treatment on the reduction of phosphorus and pathogens.

\section{Results and discussion}

\subsection{Sources of phosphorus and removal efficiencies by commonly} used DWTS

\subsubsection{Sources of phosphorus}

The main sources of phosphorus in raw domestic wastewater can be wide ranging. As an example, the source apportionment of phosphorus in raw domestic wastewater in UK is summarised in Table 1 indicating that the largest sources are human waste and detergents. These estimates can vary depending on water usage as well as diet. Consumption of a vegetarian diet has been shown to produce around half of the amount of phosphorus in human excreta compared with a meat-based diet [4]. A review by Lowe et al. [5] found the concentrations of total phosphorus (TP) in raw domestic wastewater to typically range from 13.05 to $25.8 \mathrm{mg} \mathrm{L}^{-1}$, with an average of about $19.1 \mathrm{mg} \mathrm{L}^{-1}$.

Phosphorus loading from detergents should currently represent a smaller proportion of total load from households in the EU compared with that shown in Table 1 due to EU bans on phosphates in domestic cleaning products (amendment Regulation (EU) No. 259/2012 of Regulation (EC)

Table 1

Source apportionment of phosphorus in raw domestic wastewater [6]

\begin{tabular}{ll}
\hline Source & $\begin{array}{l}\text { Contribution to } \\
\text { phosphorus load (\%) }\end{array}$ \\
\hline Faeces & 23 \\
Urine & 41 \\
Food waste & 5 \\
Mains supply (phosphate added & 5 \\
to reduce Pb in drinking water) & \\
Toothpaste & 1 \\
Dishwasher detergent & 7 \\
Laundry detergent & 18 \\
\hline
\end{tabular}

No. 648/2004), which places restrictions on the phosphate content of $\leq 0.5 \mathrm{~g}$ per standard dosage for domestic laundry from 30 June 2013 and $\leq 0.3 \mathrm{~g}$ per standard dosage for dishwasher detergents from January 2017 [7]. Regulatory limits on phosphate-containing detergents have been shown to be effective elsewhere in reducing concentrations in wastewaters and the water environment [8-11]. Another potentially significant source of phosphorus in domestic wastewater in some countries is the practice of adding orthophosphate to domestic water supplies for the reduction of plumbosolvency in areas where water supplies are still delivered, at least in part, by lead pipework. In UK, most water supplies are dosed at a level equivalent to between 1 and $2 \mathrm{mg} \mathrm{L}^{-1} \mathrm{TP}$ [12], which is equivalent to $20 \%$ of the total concentration in the effluent of an average ST [13]. Only replacement of lead components across distribution networks in many countries would remove the need for phosphorus dosing in this manner.

\subsubsection{Removal of phosphorus}

The ability of basic DWTS to remove phosphorus as standalone systems is limited. Although there is considerable variation in the overall levels of phosphorus removal across the range of DWTS, STs as standalone systems typically do not result in significant reductions. Table 2 presents the typical concentrations found in influent and effluent from STs used in a range of configurations. The effluent concentrations listed suggest that although TP concentrations vary, basic systems provide only a limited removal of TP.

The literature suggests that significant reductions are typically only achieved with additional treatments. Many phosphorus removal mechanisms have been designed as retrofit measures as ST operation alone is insufficient, where phosphorus pollution is a concern. Operational conditions may be altered to enhance removal (chemical dosing to enhance sedimentation, post-sedimentation treatment such as aeration, coagulation and flocculation to enhance removal by filtration/adsorption); however, the types of processes and filtration or adsorption media utilised will determine the overall efficiency of the removal. Physical, chemical and biological processes are all important to removal, but particularly sorption [18]. Filters are thus used as part of DWTS when space allows. Such systems include filter beds $[14,19]$ and/or subsurface flow constructed wetlands (SSF CW) $[18,20]$. Filters provide advantages such as large phosphorus adsorbing areas, typically long retention time, diversity in microbial communities and ability to alternate aerobic and anaerobic zones [18]. Vohla et al. [21] reviewed a large body of literature evaluating the phosphorus-removal properties of various filter media (natural materials, industrial by-products and man-made products), with the performance of materials used in full-scale plants shown in Table 3 [21].

The review by Vohla et al. [21] demonstrates the wide disparity in performance for various materials, with sand and peat demonstrating the best performance for natural filter media. Higher performance for some industrial by-products (blast furnace slag) has been reported; however, efficiency depends on the configuration of the system and source of the slag. Man-made products have been found to show high retention potential, with the most effective materials having a 
Table 2

Phosphorus concentrations in effluents of various septic tank (ST) configurations

\begin{tabular}{|c|c|c|c|c|c|c|}
\hline \multirow{2}{*}{$\begin{array}{l}\text { Raw water (ST } \\
\text { influent) TP }\left(\mathrm{mg} \mathrm{L}^{-1}\right)\end{array}$} & \multicolumn{3}{|c|}{ STE concentration $\left(\mathrm{mg} \mathrm{L}^{-1}\right)$} & \multirow{2}{*}{\multicolumn{2}{|c|}{ System details }} & \multirow[t]{2}{*}{ Reference } \\
\hline & SRP & \multicolumn{2}{|c|}{$\mathrm{TP}$} & & & \\
\hline $19.1(13.1-25.8)$ & - & \multicolumn{2}{|c|}{$12.2(3-39.5)$} & \multicolumn{2}{|c|}{$\begin{array}{l}\text { ST average concentrations based on literature search } \\
\text { ( } n=8 \text { for influent, } n=49 \text { for effluent) }\end{array}$} & [5] \\
\hline $13.3^{\mathrm{a}}$ & - & $7.07^{\mathrm{b}}$ & $0.22^{\mathrm{c}}$ & \multirow{4}{*}{\multicolumn{2}{|c|}{$\begin{array}{l}\text { ST plus filter bed system, results for } 4 \text { of the systems } \\
\text { tested }\end{array}$}} & \multirow[t]{4}{*}[14]{} \\
\hline $6.6^{\mathrm{a}}$ & & $5.5^{\mathrm{b}}$ & $0.04^{\mathrm{c}}$ & & & \\
\hline $26.8^{\mathrm{a}}$ & & $24.0^{\mathrm{b}}$ & $1.22^{\mathrm{c}}$ & & & \\
\hline $18.2^{\mathrm{a}}$ & & $14.0^{\mathrm{b}}$ & $0.02^{\mathrm{c}}$ & & & \\
\hline- & 1.9 & 3.3 & & \multicolumn{2}{|c|}{$\begin{array}{l}\text { Old ST; no soil adsorption bed, results for field drain } \\
\text { discharge including STE; ave. from } 1 \text { year }\end{array}$} & [15] \\
\hline- & 1.4 & 1.9 & & \multicolumn{2}{|c|}{$\begin{array}{l}\text { Old ST supplemented with modern tank. Results for } \\
\text { field drain discharge, including STE ave. from } 1 \text { year }\end{array}$} & [15] \\
\hline- & $4.8(0.3-10.6)$ & \multicolumn{2}{|c|}{$9.1(4.5-18.0)$} & \multicolumn{2}{|c|}{ Median concentrations from four STs } & {$[16]$} \\
\hline- & $8.8(2.3-11.9)$ & \multicolumn{2}{|c|}{$11.9(5.8-14.4)$} & \multicolumn{2}{|c|}{$\begin{array}{l}\text { ST with mechanical mixing. Median concentrations from } \\
\text { one ST over 4-month monitoring period }\end{array}$} & [16] \\
\hline- & $5.5(1.4-10.6)$ & \multicolumn{2}{|c|}{$9.3(1.9-14.4)$} & \multicolumn{2}{|c|}{$\begin{array}{l}\text { ST with chemical dosing and tank with aeration and } \\
\text { filter system. Median concentrations from two STs over } \\
4 \text { months }\end{array}$} & [16] \\
\hline \multirow[t]{5}{*}{-} & 11.6 & \multicolumn{2}{|l|}{15.0} & ST (concrete) & Sampled STs chosen from & [17] \\
\hline & 14.5 & \multicolumn{2}{|l|}{18.4} & ST (brick) & a range of locations across & \\
\hline & 9.4 & \multicolumn{2}{|l|}{17.4} & ST (concrete) & England & \\
\hline & 13.4 & \multicolumn{2}{|l|}{15.0} & \multicolumn{2}{|l|}{ ST (brick) } & \\
\hline & 10.7 & \multicolumn{2}{|l|}{12.9} & \multicolumn{2}{|l|}{ Klargester ${ }^{\circledR}$ PTP } & \\
\hline
\end{tabular}

a Septic tank effluent.

${ }^{\mathrm{b}}$ Outlet of biofilter.

'Outlet of filter bed.

Note: SRP - soluble reactive phosphorus; TP - total phosphorus; and PTP - package treatment plant (incorporating oxygen transfer).

pH above 7.0 and high calcium or calcium oxide content thus suggesting retention by precipitation. Other factors such as filter media particle size, hydraulic retention time and rates of organic load may affect overall performance [14,19,22]. Using a pre-treatment filter (e.g. a vertical flow pre-treatment system) to reduce the amount of organic material in wastewater may improve the efficiency of filter beds and SSF CW in terms of phosphorus removal $[19,20]$. Filter media can lose their phosphorus-sorption capacity over time as it becomes saturated $[14,21,23,24]$ but this may vary based on wastewater strength and nature of the materials. Materials such as Filtralite-P®, opoka and dehydrated oil shale ash appear to be very promising, however, may require additional testing to determine efficiency over time, and more application on large-scale plants [21]. Mineral-based sorbents can be easily replaced and potentially reused as agricultural fertiliser [19], which is particularly important as global resources of phosphorus are diminishing [25].

A comparison of the treatment efficiencies of various DWTS is summarised in Table 4. Some package treatment plants (PTPs) show improved results compared with traditional STs, but these systems tend to optimise biological uptake and settlement only. Significant removals only appear to be achieved with combination systems that allow for settlement, and filtration (CW plus filter) depending on operational features, local conditions and wastewater strength.

\subsection{Sources of pathogens and treatment efficiencies of commonly used DWTS}

\subsubsection{Sources of pathogens}

Pathogens in wastewaters are generally derived from the guts and faeces of warm-blooded animals. Hence, their occurrence in natural waters is usually from point sources such as failing cesspools, animal derived sources such as feedlots, dairy farms or intensive animal husbandry, and human-derived sources such as sewage works, combined sewer overflows or STE [31]. Human and livestock wastes can contain pathogens, including bacteria (e.g. Salmonella spp., Vibrio cholera, Shigella spp., E. coli and coliforms), viruses (e.g. Adenoviruses, Noroviruses, Hepatitis A, Echnoviruses and Coxackieviruses), protozoa (e.g. Cryptosporidium spp., Giardia spp.) and helminths [32]. The literature on the effect of various DWTS on the removal of pathogens is limited and focuses mainly on a limited number of bacterial groups of interest, typically faecal and total coliforms, E. coli and intestinal enterococci.

\subsubsection{Removal of pathogens}

Concentrations of pathogens in DWTS effluent may show a higher level of variability than centralised treatment works due to variations in household water use and wastewater production on a local scale. Table 5 summarises reported 
Table 3

Examples of phosphorus removal efficiency by different filter materials in constructed wetland systems (adapted from Vohla et al. [21])

\begin{tabular}{|c|c|c|}
\hline Material & Study type & $\mathrm{P}$ treatment efficiency \\
\hline \multirow[t]{2}{*}{ Gravel } & Three gravel based CWs, $2^{\circ}$ effluent, 2 years & $\begin{array}{l}\text { P removal }-40 \% \text { to } 40 \% \text {; range of adsorption } \\
\text { capacity }\end{array}$ \\
\hline & Full-scale CW, VSSF planted gravel filter & $\mathrm{PO}_{4}^{3-}-\mathrm{P}$ removal efficiency $4.33 \%$ \\
\hline \multirow[t]{2}{*}{ Limestone } & $\begin{array}{l}\text { Meso-scale experimental CW received effluent from } \\
\text { a treatment wetland for } 19 \text { months }\end{array}$ & TP removal $46 \%$ \\
\hline & $\begin{array}{l}\text { Full-scale CW (SSF wetland cell treating wastewater } \\
\text { from dairy farm, } 1.5 \text { years) }\end{array}$ & P removal on average $4.3 \%$, mean reduction $14.5 \%$ \\
\hline Marl gravel & $\begin{array}{l}\text { Full-scale CW, filter treating swine wastewater after } \\
\text { anaerobic lagoon treatment }\end{array}$ & TP removal $37 \%-52 \%$ \\
\hline Peat & $\begin{array}{l}\text { Small-scale CW in field (landfill leachate from activated } \\
\text { sludge plant and biopond) }\end{array}$ & $\begin{array}{l}\text { TP removal: } 77 \% \text { from sludge water, } 93 \% \text { from } \\
\text { biopond water (at } 6 \text { months) }\end{array}$ \\
\hline \multirow[t]{2}{*}{ Sand } & Full-scale CW, HSSF sand filter & P in soil after 8 years: $0.117 \mathrm{~g} \mathrm{P} \mathrm{kg}^{-1}$, removal $72 \%$ \\
\hline & Full-scale CW, HSSF sand filter & $\begin{array}{l}\text { P in sand after } 5 \text { years: } 52.8 \mathrm{mg} \mathrm{kg}^{-1} \text {, } \\
\text { removal } 78.4 \%\end{array}$ \\
\hline Shellsand & $\begin{array}{l}\text { Meso-scale CW in field, HSSF filter in greenhouse for } \\
\text { household }\end{array}$ & $335 \mathrm{~g} \mathrm{P} \mathrm{kg}^{-1}$, saturated before 2 years \\
\hline $\begin{array}{l}\text { Wollastonite } \\
\text { tailings }\end{array}$ & $\begin{array}{l}\text { Full-scale CW SSF wetland cell (wastewater from dairy } \\
\text { farm) }\end{array}$ & Soluble P removal $12.8 \%$, mean reduction: $27.5 \%$ \\
\hline Fly ash & $\begin{array}{l}\text { Full-scale CW, three-stage system, one filled with fly } \\
\text { ash }\end{array}$ & $\begin{array}{l}\text { Majority of TP absorbed by fly ash, TP removal } \\
\text { about } 83 \%\end{array}$ \\
\hline \multirow{3}{*}{$\begin{array}{l}\text { Blast furnace slag } \\
\text { (BFS) }\end{array}$} & Small-scale CW (dairy farm wastewater, 7 months) & P removal $72 \%$ \\
\hline & Full-scale CW (7 months) & TP removal up to $99 \%$ \\
\hline & Full-scale CW VSSF reed bed, granulated BFS & Average TP removal 45\% \\
\hline \multirow[t]{2}{*}{ Filtralite- $\mathrm{P}^{\circledR}$} & Small, meso- and full-scale CW & $\begin{array}{l}\text { Extracted P (mg P kg-1): 3,887 (small), 4,500 } \\
\text { (meso), } 52 \text { (full) }\end{array}$ \\
\hline & Full-scale CW, upflow filter 3 years & P removal $99.4 \%$ \\
\hline Leca (Estonian) & Full-scale CW, VSSF + HSSF filter bed, 2 years & TP removal 89\% \\
\hline LWA (Norsk Leca) & Full-scale CW (wastewater from households, 4 years) & $>95 \%$ \\
\hline Norlite & Full-scale SSF CW cell, dairy wastewater & P removal 34\% \\
\hline
\end{tabular}

Note: CW - constructed wetland; VSSF - vertical subsurface flow; HSSF - horizontal subsurface flow; SSF - subsurface flow; P - phosphorus; $\mathrm{TP}$ - total phosphorus; $\mathrm{PO}_{4}{ }^{3}-$ orthophosphate.

pathogen levels in raw wastewater and STE for the most commonly measured pathogens. The data suggest that the processes occurring in STs (which include mainly settlement in sludges, some predation by protozoa, natural die-off, adsorption onto particles and flocculation) provide only limited removal of faecal pathogens, in the order of 1-2 log reduction.

Where aerobic biological degradation is part of a DWTS treatment regime, treatment may not be significant due to the enhanced role of the microorganism in the biological treatment processes. However, where anaerobic processes are part of the treatment processes (e.g. in STs operating in tropical climate), there may be a general reduction in pathogens due to die-off of some organisms in oxygen-deficient conditions. Table 6 summarises the reported performances of various DWTS in pathogen removal. Where a DWTS consists of mainly sedimentation (e.g. STs), the level of pathogen reduction may be limited. Thus combining the DWTS with biological processes (e.g. constructed wetlands or PTPs equipped with oxygen transfer facilities) and processes that enhance predation, desiccation, ultraviolet radiation (high in tropical climate) and filtration through soil and vegetation can further enhance the effectiveness of the systems in pathogen removal.

Filtration in particular can be an important secondary treatment step in DWTS, reducing pathogen transport and increasing adsorption but effectiveness can be affected by the properties of drain fields including the soil type, texture, presence of organic matter and the formation and maintenance of a biofilm $[37,41,43]$, which can limit the efficiency of drainfields to retain pathogens [34,41,42,44,45]. The structure of the filter bed and health of the biofilm can affect the retention of pathogens, but can also influence predation by protozoa, or natural die-off (e.g. by unfavourable $\mathrm{pH}$ conditions). Adsorption within filter media can be influenced by hydraulic loading, ionic strength, $\mathrm{pH}$ and surface particle of charges [41]. Rainfall can thus affect a number of these properties and thus influence the retention of pathogens in the drainfield, potentially causing desorption and remobilisation of pathogens; therefore, performance may vary seasonally or by geographical location [38,41,46-48]. 
Table 4

Total phosphorus (TP) removal efficiencies of various DWTS

\begin{tabular}{|c|c|c|}
\hline DWTS type & $\begin{array}{l}\% \mathrm{TP} \text { reduction in } \\
\text { wastewaters }\end{array}$ & Reference \\
\hline Soil filter beds (aged 14-22 years) & 12 & [26] \\
\hline One-chambered ST & 29.3 & [27] \\
\hline Three-chambered ST & 33.1 & [27] \\
\hline Sequencing batch reactor (SBR) package treatment plant (PTP) & 87.5 & [28] \\
\hline Constructed wetland $(\mathrm{CW})$ & $\begin{array}{l}\text { Year 1: } 20 \\
\text { Year 10: } 10\end{array}$ & [24] \\
\hline CW (during the first year) & 60 & [15] \\
\hline ST plus subsurface flow CW (planted) & $95.7-98.3$ & [29] \\
\hline ST plus subsurface flow CW (unplanted) & 85.7 & [29] \\
\hline ST plus two-step vertical flow CW & 71.4 & [30] \\
\hline ST plus peat filter & $\begin{array}{l}\text { Year 1: } 50 \\
\text { Year 12: } 26.6\end{array}$ & [23] \\
\hline ST plus filter bed systems (biofilter (LWA) and media filter bed (Filtralite $\mathrm{P} 囚$ )) & $>94$ & [14] \\
\hline
\end{tabular}

Table 5

Mean pathogen concentrations in raw wastewater and septic tank effluent (STE)

\begin{tabular}{|c|c|c|c|}
\hline Parameter & $\begin{array}{l}\text { Mean concentration in raw wastewater } \\
\left(\mathrm{cfu} 100 \mathrm{~mL}^{-1}\right)\end{array}$ & $\begin{array}{l}\text { Mean concentration in STE } \\
\left(\mathrm{cfu} 100 \mathrm{~mL}^{-1}\right)\end{array}$ & Reference \\
\hline \multirow[t]{4}{*}{ Total coliforms } & $3.9 \times 10^{7}$ & $2.5 \times 10^{7}$ & [33] (UK) \\
\hline & - & $7 \times 10^{8}$ & [34] (Ireland) \\
\hline & $2.0-3.5 \times 10^{8}$ & & [35] (India) \\
\hline & $9.55 \times 10^{7}$ & $5.98 \times 10^{7}$ & [36] (Tanzania) \\
\hline \multirow[t]{5}{*}{ Faecal coliforms } & $1.2 \times 10^{7}$ & - & [37] (USA) \\
\hline & $2.0-8.0 \times 10^{7}$ & - & [35] (India) \\
\hline & $1.7 \times 10^{7}$ & $7.2 \times 10^{6}$ & [33] (UK) \\
\hline & - & $2.9 \times 10^{5}$ & [38] (USA) \\
\hline & $4.26 \times 10^{7}$ & $2.53 \times 10^{6}$ & [36] (Tanzania) \\
\hline \multirow[t]{4}{*}{ Enterococci } & $1.9 \times 10^{6}$ & $9.3 \times 10^{5}$ & [33] (UK) \\
\hline & $4.0 \times 10^{5}$ & - & [39] (Sweden) \\
\hline & $1.0 \times 10^{6}$ & - & [39] (Spain) \\
\hline & $1.3 \times 10^{6}$ & - & [39] (UK) \\
\hline \multirow[t]{2}{*}{ E. coli } & $1.2-3.3 \times 10^{6}$ & - & [35] (India) \\
\hline & - & $5.0 \times 10^{5}$ & [34] (Ireland) \\
\hline
\end{tabular}

\section{Conclusions}

Reducing the release of diffuse pollutants in rural areas is of increasing importance to environmental regulators to protect economic, environmental and human health interests. Thus, new measures to reduce the release of pollutants such as phosphorus and pathogens from DWTS must be considered. Source control measures, such as regulatory limits on phosphate containing detergents, have been shown to be effective in reducing phosphorus concentrations discharged to the environment; however, there is a limit to the level of impact these measures can have, and source control options for reducing pathogens are impractical. Furthermore, STs, which are the most common DWTS, have also been shown to be capable of providing only a limited level of treatment for the removal of phosphorus and pathogens from domestic wastewaters. Modern PTPs can provide some improvements for phosphorus removal compared with traditional STs; however, their performance is dependent on the type of package plant and post-treatment provisions. Additional post-treatments for ST effluents are thus required where the reduction of phosphorus or pathogens is needed. Filtration-based treatment systems may be effective, but their efficiency depends upon the type of filter media and their configuration. Sand, peat and alternative media filters have demonstrated good results for both phosphorus and pathogen removal. The performance has been found to reduce over time and thus will require regular maintenance to ensure 


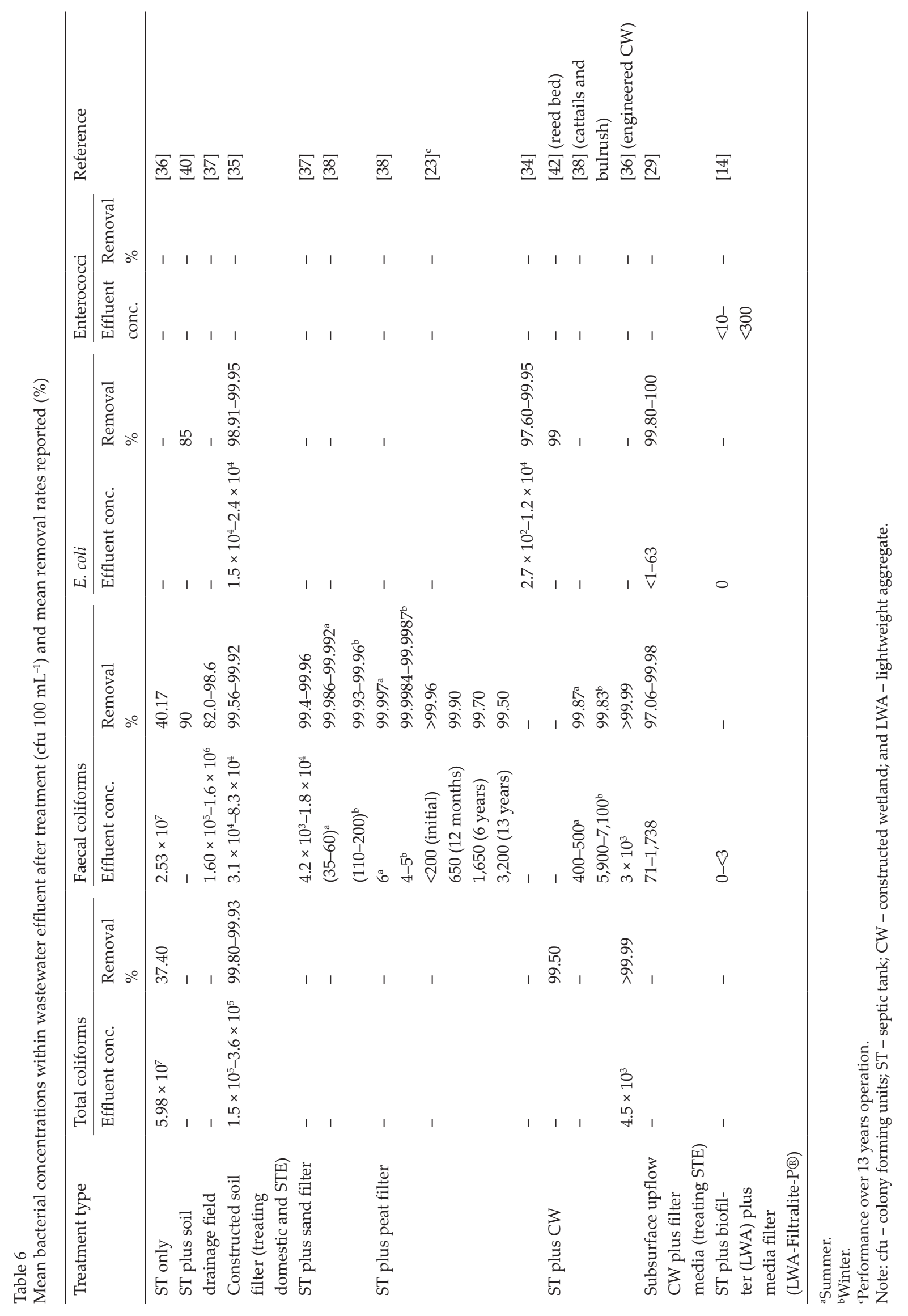


effective treatment. The performance of the filtration-based systems also depends on the type of treatment system and climatic conditions. Constructed wetland systems, including those that incorporate filter media, show good performance for the removal of both pollutants; however, site-specific conditions such as temperature, rainfall and properties of the source wastewater may all affect their performance.

It has also been found that the most effective measures for phosphorus and pathogen reduction from STEs are those measures that maximise solids reduction and also encourage favourable conditions for biological processes and microbial die-off. For effective reduction of both phosphorus and pathogens, DWTS need to be designed to production characteristics, as well as to site-specific conditions, which include consideration of input loads (e.g. use of detergents, use of phosphorus for plumbosolvency), system operational characteristics (e.g. avoiding hydraulic overload) and post-sedimentation measures (e.g. aeration facilities, use of constructed wetlands systems, and filtration and infiltration systems).

\section{Acknowledgements}

The authors would like to acknowledge the Scottish Centre of Expertise for Waters (CREW) for funding the project, and to thank Dr Linda May and her team at the UK Centre for Ecology and Hydrology for their contribution to the project.

\section{References}

[1] J. O'Keeffe, J.A. Akunna, J. Olszewska, A. Bruce, L. May, R. Allan, Practical Measures for Reducing Phosphorus and Faecal Microbial Loads from Onsite Wastewater Treatment System Discharges to the Environment. A Review, Scotland's Centre of Expertise for Waters (CREW), James Hutton Inst., Aberdeen, UK, 2015.

[2] M.I. Stutter, L. Jackson-Blake, L. May, S. Richards, A. Vinten, Factoring Ecological Significance of Sources into Phosphorus Source Apportionment, Scotland's Centre of Expertise for Waters (CREW), James Hutton Inst., Aberdeen, UK, 2014.

[3] SNIFFER, Provision of a Screening Tool to Identify and Characterise Diffuse Pollution Pressures: Phase II. Available from: http://www.sniffer.org.uk/files/4313/4183/7424/WFD19. pdf (Accessed 25 November 2014).

[4] D. Cordell, J.-O. Drangert, S. White. The story of phosphorus: global food security and food for thought, Global Environ. Change, 19 (2009) 292-305.

[5] K. Lowe, N. Rothe, J. Tomaras, K. DeJong, M. Tucholke, J. Drewes, J. McCray, J. Munakata-Marr, Influent Constituent Characteristics of the Modern Waste Stream from Single Sources: Literature Review, Water Environment Research Foundation and IWA Publishing, London, 2007.

[6] Department for Environment, Food and Rural Affairs (Defra), Consultation on Options for Controls on Phosphates in Domestic Laundry Cleaning Products in England, 2008. Available from: http://www.endseurope.com/docs/80215a.pdf (Accessed 1 October 2014).

[7] European Union. Regulation (EU) No. 259/2012 of the European Parliament and of the Council, Strasbourg, 2012.

[8] B. Alhajjar, C. Gould, G. Chesters, J. Harkin, Influence of detergent formulation on nutrient movement through sand columns simulating mound and conventional septic system drainfields, J. Contam. Hydrol., 6 (1990) 337-356.

[9] F.A. Hoffman, J.W. Bishop, Impacts of a phosphate detergent ban on concentrations of phosphorus in the James River, Virginia, Water Res., 28 (1994) 1239-1240.
[10] US Environmental Protection Agency, Onsite Wastewater Treatment Systems Manual, EPA/625/R-00/008, 2002.

[11] R.H. Foy, S.D. Lennox, C.E. Gibson, Changing perspectives on the importance of urban phosphorus inputs as the cause of nutrient enrichment in Lough Neagh, Sci. Total Environ., 310 (2003) 87-99.

[12] S. Comber, M. Gardner, K. Georges, D. Blackwood, D. Gilmour, Domestic source of phosphorus to sewage treatment works, Environ. Technol., 34 (2013) 1349-1358.

[13] L. May, C.J. Place, M. O'Malley, B. Spears, The Impact of Phosphorus Inputs from Small Discharges on Designated Freshwater Sites, Final Report to Natural England and Broads Authority, 2010.

[14] P.D. Jenssen, T. Krogstad, A.M. Paruch, T. Maehlum, K. Adam, C.A. Arias, A. Heistad, L. Jonsson, D. Hellström, H. Brix, M. YliHalla, L. Vråle, M. Valve, Filter bed systems treating domestic wastewater in the Nordic countries - performance and reuse of filter media, Ecol. Eng., 36 (2010) 1651-1659.

[15] M.C. Ockenden, J.N. Quinton, N. Favaretto, C. Deasy, B. Surridge, Reduced nutrient pollution in a rural stream following septic tank upgrade and installation of runoff retention measures, Environ. Sci. Process. Impacts, 16 (2014) 1637-1645.

[16] W. Brownlie, L. May, C. MacDonald, S. Roaf, B.M. Spears, Assessment of a novel development policy for the control of phosphorus losses from private sewage systems to the Loch Leven catchment, Scotland, UK, Environ. Sci. Policy, 38 (2014) 207-216.

[17] L. May, P.J. Withers, C. Stratford, M. Bowes, D. Robinson, E. Gozzard, Development of a Risk Assessment Tool to Assess the Significance of Septic Tanks around Freshwater SSSIs: Phase 1 - Understanding Better the Retention of Phosphorus in the Drainage Fields, Report to Natural England NECR171, 2014.

[18] M. Kõiv, C. Vohla, R. Mõtlep, M. Liira, K. Kirsimäe, Ü. Mander, The performance of peat-filled subsurface flow filters treating landfill leachate and municipal wastewater, Ecol. Eng., 35 (2009) 204-212.

[19] C. Nilsson, R. Lakshmanan, G. Renman, G.K. Rajarao, Efficacy of reactive mineral-based sorbents for phosphate, bacteria, nitrogen and TOC removal - column experiment in recirculation batch mode, Water Res., 47 (2013) 5165-5175.

[20] T. Mæhlum, P. Stålnacke, Removal efficiency of three coldclimate constructed wetlands treating domestic wastewater: effects of temperature, seasons, loading rates and input concentrations, Water Sci. Technol., 40 (1999) 273-281.

[21] C. Vohla, M. Kõiv, H.J. Bavor, F. Chazarenc, Ü. Mander, Filter materials for phosphorus removal from wastewater in treatment wetlands - a review, Ecol. Eng., 37 (2011) 70-89.

[22] C. Nilsson, G. Renman, L. Johansson Westholm, A. Renman, A. Drizo, Effect of organic load on phosphorus and bacteria removal from wastewater using alkaline filter materials, Water Res., 47 (2013) 6289-6297.

[23] R.A. Patterson, Peat Treatment of Septic Tank Effluent, R. Patterson, Ed., Proc. Onsite '99 Conference: Making On-site Wastewater Systems Work, Armidale, New South Wales, 1999, pp. 273-281.

[24] M.A. Duenas, C.J. Stratford, S. Mackenzie, Nutrient Dynamics in a Semi-natural Treatment Reedbed, Poster, Constructed Wetlands Conference: Reducing Rural Pollution Risk, Edinburgh, 2007. Available from: http://nora.nerc.ac.uk/10014/ (Accessed 1 October 2014).

[25] D. Cordell, S. White, Peak phosphorus: clarifying the key issues of a vigorous debate about long-term phosphorus security, Sustainability, 3 (2011) 2027-2049.

[26] D. Eveborn, D. Kong, J.P. Gustafsson, Wastewater treatment by soil infiltration: long-term phosphorus removal, J. Contam. Hydrol., 140-141 (2012) 24-33.

[27] F.A. Nasr, B. Mikhaeil, Treatment of domestic wastewater using conventional and baffled septic tanks, Environ. Technol., 34 (2013) 2337-2343.

[28] J. Akunna, C. Jefferies, Performance of family-size sequencing batch reactor and rotating biological contactor units treating sewage at various operating conditions, Water Sci. Technol., 41 (2000) 97-104. 
[29] N.-B. Chang, Z. Xuan, A. Daranpob, M. Wanielista, A subsurface upflow wetland system for removal of nutrients and pathogens in on-site sewage treatment and disposal systems, Environ. Eng. Sci., 28 (2011) 11-25.

[30] A. Nguyen, N. Pham, T. Nguyen, A. Morel, K. Tonderski, Improved septic tank with constructed wetland, a promising decentralised wastewater treatment alternative in Vietnam, NOWRA 16th Annual Technical Education Conference \& Exposition, Baltimore, Maryland, 2007.

[31] B. Macler, J. Merkle, Current knowledge of groundwater microbial pathogens and their control, Hydrogeol. J., 8 (2000) 29-40.

[32] S. Malham, P. Rajko-Nenow, E. Howlett, K. Tuson, T. Perkins, D. Pallett, H. Wang, C. Jago, D. Jones, J. McDonald, The interaction of human microbial pathogens, particulate material and nutrients in estuarine environments and their impacts on recreational and shellfish waters, Environ. Sci. Process. Impacts, 16 (2014) 2145-2155.

[33] D. Kay, J. Crowther, M. Stapleton, M. Wyer, L. Fewtrell, A. Edwards, C. Francis, A. McDonald, J. Watkins, J. Wilkinson, Faecal indicator organism concentrations in sewage and treated effluents, Water Res., 42 (2008) 442-454.

[34] L. Gill, C. O'Súilleabháin, B. Misstear, P. Johnston, The treatment performance of different subsoils in Ireland receiving on-site wastewater effluent, J. Environ. Qual., 36 (2007) 1843-1855.

[35] A. Kadam, G. Oza, P. Nemade, H. Shankar, Pathogen removal from municipal wastewater in constructed soil filter, Ecol. Eng., 33 (2008) 37-44.

[36] S. Mbuligwe, Applicability of a Septic Tank/Engineered Wetland Coupled System in the Treatment and Recycling of Wastewater from a Small Community, Environ. Manage., 35 (2005) 99-108.

[37] R. Harrison, N. Turner, J. Hoyle, J. Krejsl, D. Tone, C. Henry, P. Isaksen, D. Xue, Treatment of septic effluent for fecal coliform and nitrogen in coarse-textured soils: use of soil-only and sand filter systems, Water Air Soil Pollut., 124 (2000) 205-215.

[38] J. Pundsack, R. Axler, R. Hicks, J. Henneck, D. Nordman, B. McCarthy, Seasonal pathogen removal by alternative on-site wastewater treatment systems, Water Environ. Res., 73 (2001) 204-212.
[39] A. Blanch, J. Caplin, A. Iversen, I. Kühn, A. Manero, H. Taylor, X. Vilanova, Comparison of enterococcal populations related to urban and hospital wastewater in various climatic and geographic European regions, J. Appl. Microbiol., 94 (2003) 994-1002.

[40] J. Tomaras, J. Sahl, R. Siegrist, J. Spear, Microbial diversity of septic tank effluent and a soil biomat, Appl. Environ. Microbiol., 75 (2009) 3348-3351.

[41] T. Stevik, K. Aa, G. Ausland, J. Hanssen, Retention and removal of pathogenic bacteria in wastewater percolating through porous media: a review, Water Res., 38 (2004) 1355-1367.

[42] N. O'Luanaigh, P. Johnston, B. Misstear, T. Patel, L. Gill, A comparative study on the treatment performance of a conventional septic tank system and reed bed-soil absorption system receiving domestic effluent, Desal. Wat. Treat., 4 (2009) $45-53$.

[43] L. Pang, M. Close, M. Goltz, L. Sinton, H. Davies, C. Hall, G. Stanton, Estimation of septic tank setback distances based on transport of E. coli and F-RNA phages, Environ. Int., 29 (2003) 907-921.

[44] C. Beal, E. Gardner, G. Kirchhof, N. Menzies, Long-term flow rates and biomat zone hydrology in soil columns receiving septic tank effluent, Water Res., 40 (2006) 2327-2338.

[45] N. O'Luanaigh, L. Gill, B. Misstear, P. Johnston, The attenuation of microorganisms in on-site wastewater effluent discharged into highly permeable subsoils, J. Contam. Hydrol., 142-143 (2012) 126-139.

[46] L.J. Arnade, Seasonal correlation of well contamination and septic tank distance, Ground Water, 37 (1999) 920-923.

[47] G. Chen, S. Walker, Role of solution chemistry and ion valence on the adhesion kinetics of groundwater and marine bacteria, Langmuir, 23 (2007) 7162-7169.

[48] A. Okoh, T. Sibanda, S. Gusha, Inadequately treated wastewater as a source of human enteric viruses in the environment, Int. J. Environ. Res. Public Health, 7 (2010) 2620-2637. 